\title{
Domestic Combustion of Biomass Fuels in Developing Countries: A Major Source of Atmospheric Pollutants
}

\author{
J. LUDWIG, L. T. MARUFU, B. HUBER, M. O. ANDREAE and G. HELAS ${ }^{\star}$ \\ Max Planck Institute for Chemistry, Biogeochemistry Department, PO Box 3060, D-55020 Mainz, \\ Germany,e-mail: gth@mpch-mainz.mpg.de
}

(Received: 7 June 2000; in final form: 13 March 2002)

\begin{abstract}
Biomass burning has important impacts on atmospheric chemistry and climate. Fires in tropical forests and savannas release large quantities of trace gases and particulate matter. Combustion of biofuels for cooking and heating constitutes a less spectacular but similarly widespread biomass burning activity. To provide the groundwork for a quantification of this source, we determined in rural Zimbabwe the emissions of $\mathrm{CO}_{2}, \mathrm{CO}$, and $\mathrm{NO}$ from more than 100 domestic fires fueled by wood, agricultural residues, and dung. The results indicate that, compared to open savanna fires, emissions from domestic fires are shifted towards products of incomplete combustion. A tentative global analysis shows that the source strength of domestic biomass burning is on the order of $1500 \mathrm{Tg} \mathrm{CO}_{2}-\mathrm{C} \mathrm{yr}^{-1}, 140 \mathrm{Tg} \mathrm{CO}-\mathrm{C} \mathrm{yr}^{-1}$, and $2.5 \mathrm{Tg} \mathrm{NO}-\mathrm{N} \mathrm{yr}^{-1}$. This represents contributions of about 7 to $20 \%$ to the global budget of these gases.
\end{abstract}

Key words: domestic biofuel, emissions.

\section{Introduction}

Combustion of fuelwood, charcoal, and nonwoody biofuels is a daily practice for about half of the world's population. Most of this domestic biomass burning takes place in the developing world, where, mainly due to economic reasons, vital energy needs for cooking, heating, and lighting have to be met by biofuels. In many rural regions on the African continent more than $90 \%$ of the energy requirements are met by biofuels (Floor and van der Plas, 1992; Hall and Mao, 1994; Woods and Hall, 1994; Marufu et al., 1999). An environmental problem most often associated with fuelwood use is deforestation, which happens wherever woodfuels are used unsustainably. Concern exists also about serious health effects due to the exposure to elevated indoor pollution levels resulting from domestic fires (Smith et al., 1983; de Koning et al., 1985; Brauer et al., 1996; Venkataraman and Rao, 2001). Recently, it has been demonstrated that, in addition to the problems mentioned above, trace gases and aerosols released through biomass burning have a significant influence

\footnotetext{
^ Author for correspondence.
} 
on climate and biogeochemical cycles (Crutzen and Andreae, 1990; Levine, 1991, 1996; Andreae, 1993; Liousse et al., 1997; Christopher et al., 2000).

Unlike wild fires, which are a seasonal phenomenon (Cahoon et al., 1992), domestic biomass burning for energy generation constitutes a continuous input of trace compounds into the atmosphere. The scattered and small-scale nature of domestic biomass burning is one of the reasons why only little information is available. Furthermore, since much of the fuel is obtained by individual gathering and not marketed, adequate statistics on fuel use are not kept. Research in this area requires information on two subjects: the consumption of biofuels, and the emission of constituents per unit quantity of burned fuel (emission factors). For the first topic, information has been collected mainly under the aspect of energy policy issues (Floor and van der Plas, 1992; Hall and Mao, 1994; Leach and Gowen, 1987; Hall et al., 1994; Woods and Hall, 1994; Marufu et al., 1997, 1999; Kituyi et al., 2001a,b). Assessments of the emission factors for domestic biofuel combustion in developing countries, however, have rarely been done, and we have therefore focused our work on this aspect. For this purpose, we obtained a large data set of emission factors from on-line measurements of $\mathrm{CO}_{2}, \mathrm{CO}$, and $\mathrm{NO}$ during domestic combustion in rural Africa. A major part of our field research took place in Zimbabwe, where we also investigated biofuel consumption rates and patterns by means of a questionnaire survey. Combination of experimental results and biofuel statistics enabled us to estimate the regional and global impact of emissions from domestic biomass burning.

The traditional practice in rural Zimbabwe is that fires are prepared inside a hut separate from the main house. A circular, gentle depression in the ground serves as the fireplace. The common cooking procedure involves no device other than a metal frame that is erected above the fireplace for holding pots. Fuelwood is usually stacked up to a radial pile and ignited with the help of a small amount of inflammable material (dry grass, plastics). Depending on the desired effect, fire control is done by means of fuel reloads, removal of burning fuel, and fanning or blowing. Exhaust gases are released into the room, which is ventilated through the doorway, the windows, and a small gap between the wall and the roof.

\section{Experimental}

The experimental setup was designed in a way that allowed continuous monitoring of major combustion products with least disturbance of the cooking procedures. The layout of the setup was adapted from a previously used laboratory unit (Lobert, 1989). A mobile sampling chimney was erected some distance above the fireplace, thus leaving enough space for managing the fire and cooking. The chimney, shaped like an upside-down funnel, was adjustable in height and equipped with a fan to maintain a vertical airflow sufficient for the analyzers during the whole combustion session without agitating the fire (Lobert, 1989). An aliquot of the stack gas was continuously pumped from the center of the sampling chimney to analyzers placed 
on a vehicle outside the hut. For protection of the instruments, the gas samples were drawn through glass-fiber and Teflon filters. Analysis involved nondispersive infrared analyzers for $\mathrm{CO}_{2}$ and $\mathrm{CO}$ and a chemiluminescence analyzer for $\mathrm{NO}$. All measurements included the determination of indoor background levels of these compounds. Stack gas temperature, flow rate in the chimney, and the weights of fuel burned and ash generated were also determined.

\section{Results and Discussion}

Figure 1 shows the temporal behavior of the parameters measured in the course of a fire session. The mixing ratios of $\mathrm{CO}_{2}, \mathrm{CO}$, and $\mathrm{NO}$ are presented as well as the stack gas temperature and the ratios of excess $\mathrm{CO}$ and NO relative to excess $\mathrm{CO}_{2}$. Excess, or $\Delta$ here, is the mixing ratio of the trace compound of interest above background values. In a few cases, less than $10 \%$, data had to be discarded due to excessive variations in background mixing ratios. Background values of $\mathrm{CO}_{2}$ before the combustion session typically were below $400 \mathrm{ppm}$ and rose towards the end to mixing ratios between 500 and $600 \mathrm{ppm}$. The fire session shown here in Figure 1 started at 17:35 local time with an initial load of $3.95 \mathrm{~kg}$ pine wood, later followed by two reloads combined with fanning. The temperature sequence at the sampling point indicates that the intensity of the combustion was highest shortly after the initial load and reached further maxima after both reloads. A strong positive correlation can be seen in the time series of temperature and the mixing ratio of $\mathrm{CO}_{2}$ and $\mathrm{NO}$. This correlation shows that $\mathrm{CO}_{2}$ and $\mathrm{NO}$ are mainly formed during the hot periods of a fire. The mixing ratio of $\mathrm{CO}$ shows a totally different pattern. The maximum $\mathrm{CO}$ mixing ratio is reached towards the end of the fire, when $\mathrm{CO}_{2}$ approaches background levels. The ratio of $\Delta \mathrm{CO}$ to $\Delta \mathrm{CO}_{2}$ is an indicator of the prevalent combustion conditions at any given time. A low $\Delta \mathrm{CO} / \Delta \mathrm{CO}_{2}$ ratio indicates periods of high-temperature, flaming (i.e., relatively complete) combustion, whereas a high ratio is associated with low-temperature, smoldering (i.e., incomplete) combustion. In the given example, flaming conditions developed after the initial load and after both reloads, but smoldering conditions prevailed each time the fire was allowed to burn down. The firing practice in regards to reload and to, a smaller extent, fanning by the person in charge of the fire had a strong influence on whether flaming or smoldering combustion developed. The larger part of fuel is normally burned during the flaming phases.

To summarize and compare individual fires, we integrated the emission of each compound over the entire combustion session and calculated ratios of the integrated release. This procedure yields integral emission ratios for each fire, and, unlike cylinder or Teflon bag sampling, it does not necessitate the aggregation and weighting of measurements according to the different combustion phases. We express our $\Delta \mathrm{CO} / \Delta \mathrm{CO}_{2}$ and $\Delta \mathrm{NO} / \Delta \mathrm{CO}_{2}$ emission ratios as $\mathrm{mmol} \mathrm{mol}^{-1}$ (mole substance per 1000 moles of $\left.\mathrm{CO}_{2}\right)$ and summarize them in Figures $2(\mathrm{a}, \mathrm{b})$. The data are valid for the typical wood species available (for details, Marufu et al., 1999). 

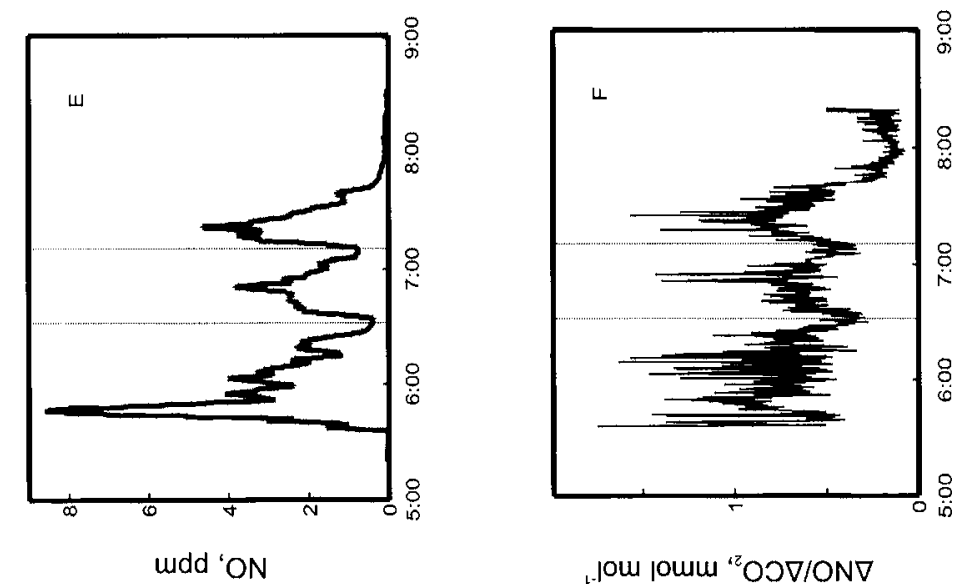

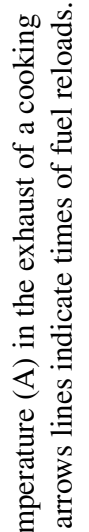

1. IOU joum " OOD/OND
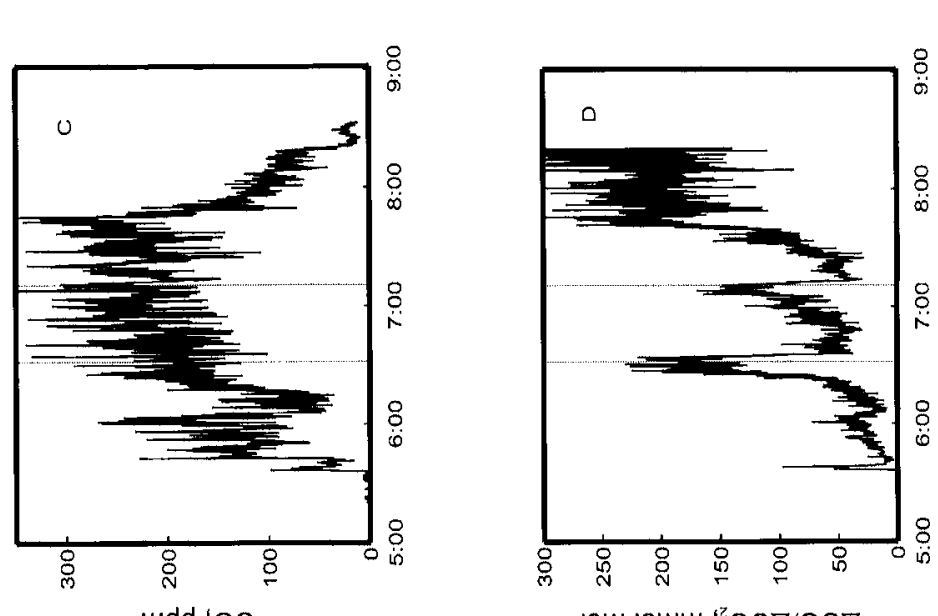

פ

के

I

可

。음

끌

들

.

ป

ฮै

$\ddot{\widehat{\Theta}} \dot{v}$

.jou joum "OOV/OOD

乙
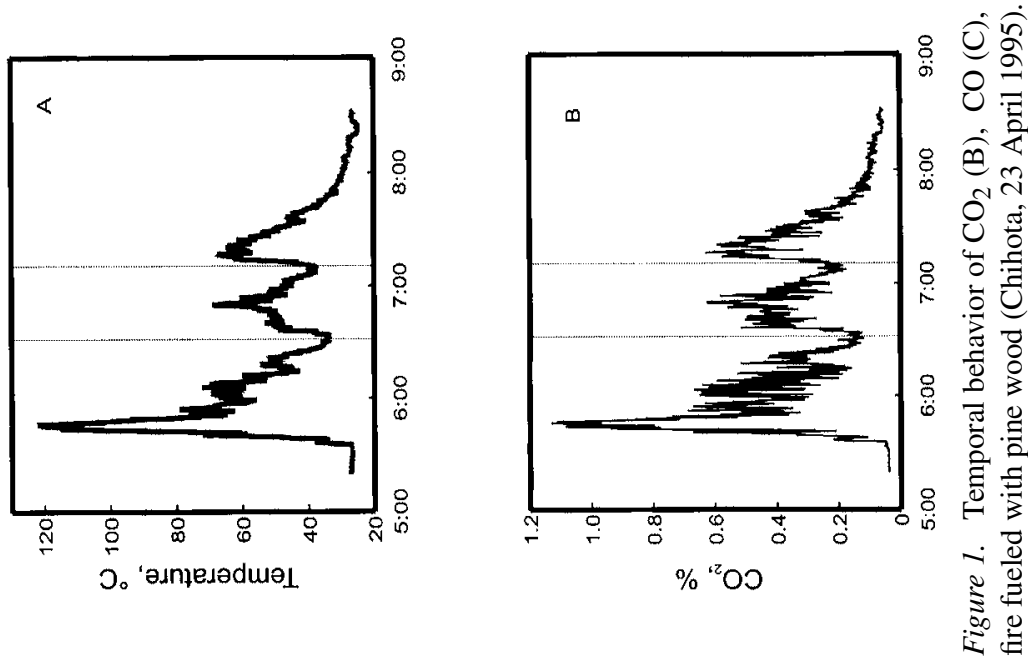
For comparison, 29 measurements which we performed in Nigeria in July 1995 are also presented.

The observed range for the $\Delta \mathrm{CO} / \Delta \mathrm{CO}_{2}$ ratio is between 41 and $146 \mathrm{mmol}$ $\mathrm{mol}^{-1}$ for a total of 103 fires in Zimbabwe, well within the range that is generally attributed to biomass burning (Andreae, 1993). Values obtained in Nigeria range from 66 to $119 \mathrm{mmol} \mathrm{mol}^{-1}$ and do not deviate from the Zimbabwean results, although a different firing method (three-stone stove) was used in Nigeria. The range of variation in the observed emission ratios can be attributed to the different fuel types and to differences in moisture content and in size and shape of the fuel. To determine the influence of fuelwood-log size, each emission measurement in 1996 was complemented by the determination of fuelwood dimensions. Because a complex mixture of twigs, branches, and trunks was often loaded in the course of a single cooking session, it is difficult to define for a given fire the average log size that relates to the corresponding $\Delta \mathrm{CO} / \Delta \mathrm{CO}_{2}$ emission ratio. A simple relationship, however, can be derived if we consider only fires that were fed by fuelwood of a fairly uniform size and classify them according to the prevailing diameter (d) into fires fueled by small $(d \leqslant 0.01 \mathrm{~m})$, medium $(0.01 \mathrm{~m}<d<0.05 \mathrm{~m})$, and large $(0.05 \mathrm{~m} \leqslant d)$ matter. The average $\Delta \mathrm{CO} / \Delta \mathrm{CO}_{2}$ emission ratios (mean \pm standard deviation) calculated are $79 \pm 23 \mathrm{mmol} \mathrm{mol}^{-1}(n=6), 95 \pm 21 \mathrm{mmol}$ $\mathrm{mol}^{-1}(n=19)$, and $113 \pm 18 \mathrm{mmol} \mathrm{mol}^{-1}(n=11)$ for fires fed by small, medium, and large wood logs, respectively. The increase in the $\Delta \mathrm{CO} / \Delta \mathrm{CO}_{2}$ emission ratio with the diameter of the fuelwood logs is mainly due to the specific combustion processes occurring within a fire. The higher surface-to-mass ratio of smaller wood pieces results in a higher rate of heat production and hence supports high-temperature (i.e., flaming) combustion. In addition, fires fueled by small matter die down quickly after the end of active cooking, whereas large-size branches and trunks often remain smoldering for up to hours unattended. Therefore, the use of large fuel material is related to an extended smoldering period at the end of a fire. Maize cob and dung fires show low $\Delta \mathrm{CO} / \Delta \mathrm{CO}_{2}$ emission ratios (Figure 2), i.e., efficient combustion, presumably because these fuels are only available in the form of small pieces with combustion characteristics similar to those of small-size woodlogs. The rather low $\Delta \mathrm{CO} / \Delta \mathrm{CO}_{2}$ emission ratio observed for maize cobs is likely caused by its low density, which is a fuel attribute known to favor more efficient combustion. The influence of the moisture content of the fuelwood can be seen from a comparison of measurements performed during a period of drought (April-May 1995) and those which took place during rainy conditions (FebruaryMarch 1996). The moisture content of the utilized fuelwood was determined to be $9 \%$ mcdb (moisture content on dry basis (mass of moist fuel - mass of dried fuel)/mass of dried fuel) during the dry period but, unfortunately, could not be obtained during the wet period; however, according to Leach and Gowen (1987), the typical moisture content of wood for this period should be around $20 \%$. This higher moisture content resulted in a slight increase in the $\Delta \mathrm{CO} / \Delta \mathrm{CO}_{2}$ emission ratio from $78 \pm 15 \mathrm{mmol} \mathrm{mol}^{-1}\left(n=15\right.$, dry period) to $98 \pm 24 \mathrm{mmol} \mathrm{mol}^{-1}$ 
( $n=33$, wet period) for fires fueled with the wood species (pine, musasa, eucalyptus) that were available during both seasons. However, it should be noted that the seasonal difference in the overall means of fuelwood fires is just visible but not significant $\left(92 \pm 22 \mathrm{mmol} \mathrm{mol}^{-1}, n=26\right.$, dry season compared to $97 \pm 24 \mathrm{mmol}$ $\mathrm{mol}^{-1}, n=68$, wet season).

The $\Delta \mathrm{NO} / \Delta \mathrm{CO}_{2}$ emission ratio (Figure 2(b)) for fuelwood is generally close to $1 \mathrm{mmol} \mathrm{mol}^{-1}$, with $67 \%$ of all measurements in Zimbabwe $(n=94)$ ranging between 0.7 and $1.4 \mathrm{mmol} \mathrm{mol}^{-1}$. Again results from Zimbabwe and Nigeria do not differ significantly. Pronounced differences, however, can be noticed between the combustion of the three types of fuel used in the present study. The average $\Delta \mathrm{NO} / \Delta \mathrm{CO}_{2}$ ratio of the six fires that predominantly utilized maize cobs is about three times higher than the ratio of fires fueled by wood. Dung fires had even higher $\Delta \mathrm{NO} / \Delta \mathrm{CO}_{2}$ ratios averaging $8.6 \mathrm{mmol} \mathrm{mol}^{-1}$. Laboratory studies have demonstrated that the $\mathrm{NO}_{x}$ released during biomass burning originates from the nitrogen which is fixed in the burned material and that $\Delta \mathrm{NO}_{x} / \Delta \mathrm{CO}_{2}$ emission ratios will therefore increase with the nitrogen content of the biomass (Clements and McMahon, 1980). As typical N-contents for wood, maize residues, and cattle dung are $0.2-0.3 \%, 0.6-1.4 \%$ and 1.2-3.0\%, respectively, (Lobert, 1989; Barnard, 1990; Susott et al., 1996), our observations are in agreement with these findings. The number of observations for residues and dung fires, however, is fairly low, and emissions from combustion of these fuels need to be further investigated.

The observed $\Delta \mathrm{NO} / \Delta \mathrm{CO}_{2}$ ratios also show dependencies on moisture content, decreasing in the wet period by up to $20 \%$ for some fuelwood species (e.g., pine, musasa). The decrease in the $\Delta \mathrm{NO} / \Delta \mathrm{CO}_{2}$ ratio in the course of individual fire sessions during the smoldering phases (Figure 1) indicates that the combustion efficiency has an influence on the emission of $\mathrm{NO}$ relative to $\mathrm{CO}_{2}$. However, compared to the strong impact of fuel nitrogen on the release of $\mathrm{NO}$, the influence of combustion characteristics is of minor importance.

For the purpose of generalization, we have calculated average emission ratios for the three types of biofuel used. These ratios are presented in Table I and compared with values recently published (Andreae, 1993; Brocard et al., 1996; Brocard and Lacaux, 1998). The average $\Delta \mathrm{CO} / \Delta \mathrm{CO}_{2}$ emission ratio of all domestic fuelwood fires in Zimbabwe is $95 \mathrm{mmol} \mathrm{mol}^{-1}$, which is somewhat higher than the value of $79 \mathrm{mmol} \mathrm{mol}^{-1}$ derived by Brocard et al. (1996) from Teflon bag samples collected during different stages of fuelwood fires in Côte d'Ivoire. A ratio of $100 \mathrm{mmol} \mathrm{mol}^{-1}$ is given by Smith et al. (1993) for a limited number of exhaust gases samples from domestic wood combustion in the Philippines. We therefore propose a $\Delta \mathrm{CO} / \Delta \mathrm{CO}_{2}$ value of $95 \mathrm{mmol} \mathrm{mol}^{-1}$ as typical for domestic wood fires in developing countries. This value is higher than the value of $80 \mathrm{mmol} \mathrm{mol}^{-1}$ suggested by Andreae (1993) as representative for biomass burning in general and, thus, means that the formation of reduced or partially oxidized combustion products is more favored during domestic biomass burning. 

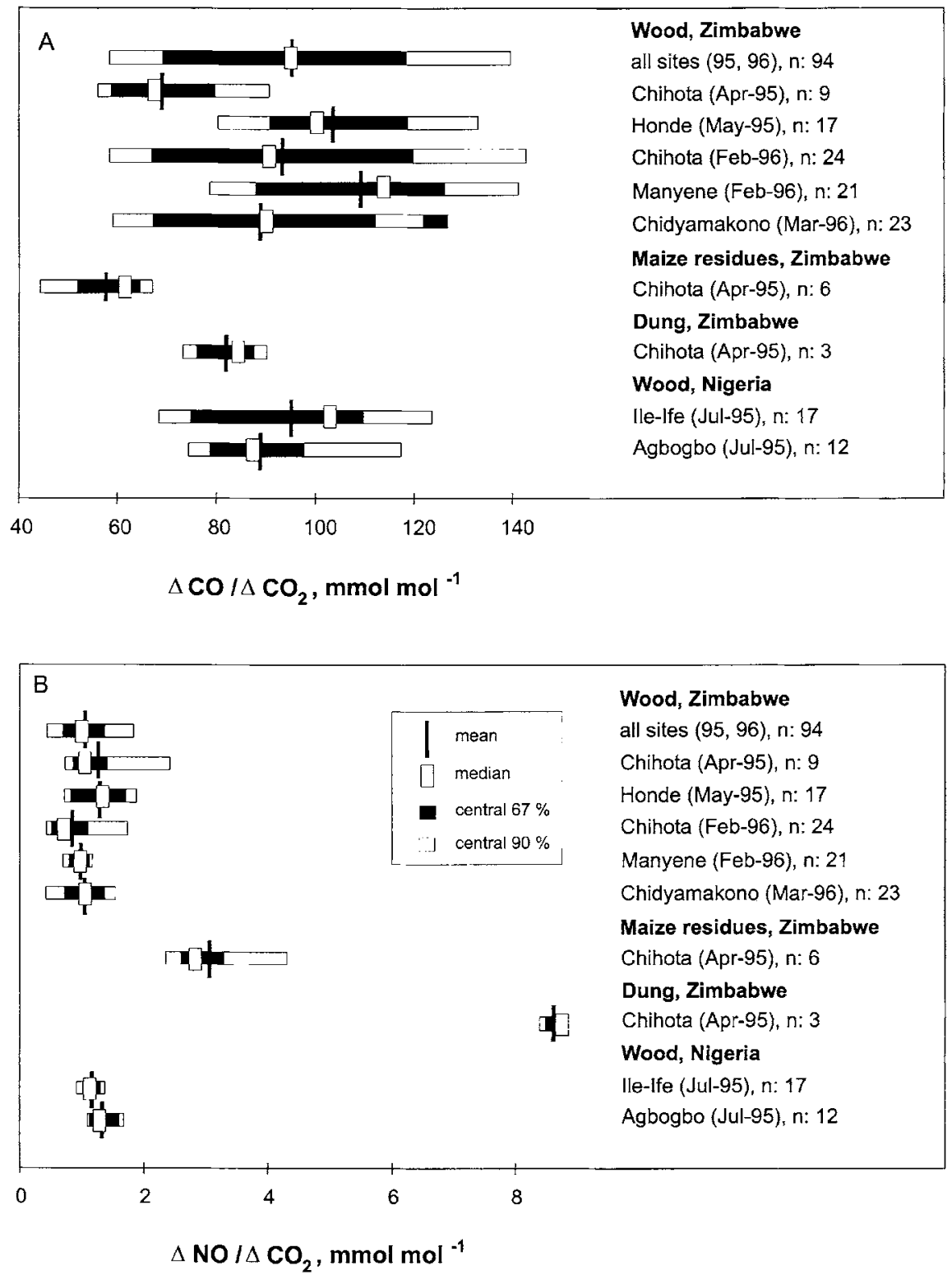

Figure 2. The statistical distribution of the integrated ratios $\Delta \mathrm{CO} / \Delta \mathrm{CO}_{2}$ (A) and $\Delta \mathrm{NO} / \Delta \mathrm{CO}_{2}$ (B) observed during domestic combustion of different biofuels at several locations in Zimbabwe. For comparison, results from domestic fires in Nigeria are included. 
Table I. Average emission ratios and emission factors observed during domestic combustion of different biofuels in rural Zimbabwe. Results are compared with measurements from western Africa (Brocard et al., 1996; Brocard and Lacaux, 1998) and with global means for biomass burning (Andreae, 1993). Emission ratios are expressed in moles per 1000 moles of $\mathrm{CO}_{2}$, while emission factors are given in gram $\mathrm{C}$ or $\mathrm{N}$ per kilogram dry fuel

\begin{tabular}{|c|c|c|c|c|c|}
\hline \multirow[t]{2}{*}{ Type of fuel } & \multicolumn{2}{|c|}{ Emission ratios } & \multicolumn{3}{|c|}{ Emission factors } \\
\hline & $\Delta \mathrm{CO} / \Delta \mathrm{CO}_{2}$ & $\Delta \mathrm{NO} / \Delta \mathrm{CO}_{2}$ & $\mathrm{CO}_{2}$ & $\mathrm{CO}$ & $\mathrm{NO}$ \\
\hline \multicolumn{6}{|l|}{ Zimbabwe } \\
\hline Fuelwood $(n=94)$ & 95 & 1.0 & 450 & 43 & 0.52 \\
\hline Maize residues $(n=6)^{\mathrm{a}}$ & 58 & 3.1 & 469 & 27 & 1.70 \\
\hline Cattle dung $(n=3)$ & 82 & 8.6 & 439 & 36 & 4.41 \\
\hline \multicolumn{6}{|l|}{ Western Africa ${ }^{b}$} \\
\hline Fuelwood & 79 & $1.5^{\mathrm{c}}$ & 400 & 30 & $0.69^{\mathrm{c}}$ \\
\hline Charcoal & & & $290^{\mathrm{d}}$ & $55^{d}$ & \\
\hline Biomass - global mean & 80 & $2.3^{\mathrm{c}}$ & & & \\
\hline
\end{tabular}

${ }^{a}$ Maize residues are normally used in combination with fuelwood. Here we summarize those fires for which residues were the predominant fuel (at least 50\% of burnt fuel).

${ }^{\mathrm{b}}$ From Brocard et al. (1996) and Brocard and Lacaux (1998).

${ }^{\mathrm{c}}$ Given for $\mathrm{NO}_{x}\left(\mathrm{NO}+\mathrm{NO}_{2}\right)$.

$\mathrm{d}$ Given per kg of dry wood for the making and burning of charcoal.

In contrast, the average $\Delta \mathrm{NO} / \Delta \mathrm{CO}_{2}$ emission ratio obtained for fuelwood fires is lower than the representative values for the combustion of most biomass types (Andreae, 1993). This is reasonable, considering the relatively low nitrogen content of wood. Our average of $1.0 \pm 0.4 \mathrm{mmol} \mathrm{mol}^{-1}$ is furthermore consistent with the emission ratio of $1.5 \pm 0.4 \mathrm{mmol} \mathrm{mol}^{-1}$ reported for fuelwood fires in Côte d'Ivoire (Brocard et al., 1996; Brocard and Lacaux, 1998), particularly if we consider that the latter emission ratio is given for $\mathrm{NO}_{x}$ (the sum of $\mathrm{NO}$ and $\mathrm{NO}_{2}$ ). After adjusting for the emission ratio of $\mathrm{NO}$ to $\mathrm{NO}_{2}$, which according to Delmas et al. (1995) is approximately 9 to 1 , the discrepancy between the results is below $40 \%$. However, low $\Delta \mathrm{NO} / \Delta \mathrm{CO}_{2}$ emission ratios observed for wood fires are not typical for all biomass fuels and should not be generalized to all domestic biomass burning. The average $\Delta \mathrm{NO} / \Delta \mathrm{CO}_{2}$ emission ratio for dung fires $(8.6 \pm 0.2$ mmol mol$\left.{ }^{-1}\right)$ is amongst the highest values observed in biomass burning studies (Andreae, 1993), indicating that information on the representative biofuel mix is necessary to draw definite conclusions regarding the contribution of domestic burning to the pyrogenic NO release.

Estimation of emissions from fuel-use statistics requires the knowledge of emission factors, i.e., the mass of a compound released during the combustion per unit mass of dry fuel. First, carbon mass balance is used to derive the emission factor for $\mathrm{CO}_{2}$. Then, emission ratios of other compounds relative to $\mathrm{CO}_{2}$ can be used 
to calculate their corresponding emission factors. A carbon content of about 50\% has been reported for a variety of biofuels (Susott et al., 1996) and will be used in the following calculation. Determination of ash weights showed that the portion of ash relative to the burned fuel is quite low with averages of $6.6 \pm 2.8 \%(n=81)$ for wood, $3.2 \pm 0.7 \%(n=3)$ for maize residues, and $22.6 \pm 1.8 \%(n=3)$ for dung. Applying a value of $11 \%$ for the carbon content of ash (Brocard et al., 1996; Brocard and Lacaux, 1998) yields 4 to $25 \mathrm{~g}$ as the amount of carbon per $\mathrm{kg}$ of burnt fuel that remains in the ash. The remaining carbon of the initial fuel will be released to the atmosphere. An exact calculation of emission factors requires the knowledge of all carbon compounds released, which are mainly $\mathrm{CO}_{2}, \mathrm{CO}, \mathrm{CH}_{4}$, nonmethane hydrocarbons (NMHC), organic acids, and particulate matter. However, as carbon emissions consist predominantly of $\mathrm{CO}_{2}$ and $\mathrm{CO}$, the approximation that is made by calculating emission factors from these two compounds (the emission factors obtained are included in Table I) will not introduce any significant error. This view is supported by the results of Brocard et al. (1996) and Brocard and Lacaux (1998), who reported that compounds other than $\mathrm{CO}_{2}$ and $\mathrm{CO}$ represent only $2 \%$ of the total carbon released during the combustion of fuelwood.

Concurrent to the emission measurements, we studied biofuel consumption rates and patterns in Zimbabwe (Marufu et al., 1997, 1999). Average fuelwood consumption rates established at four rural sites in Zimbabwe during the dry season of 1995 ranged from 1.79 to $4.46 \mathrm{~kg} \mathrm{cap}^{-1} \mathrm{day}^{-1}$. Higher consumption rates were observed in areas with abundant wood supply, whereas lower rates were associated with situations of wood scarcity. Wood scarcity, however, had further consequences for the biofuel use. A higher percentage of fuelwood had to be obtained from commercial sources, so that fuel supply became an economic factor. Furthermore, the proportion of households which used agricultural residues and dung, or, if economically feasible, kerosene was higher in areas with wood scarcity.

Annualized average rural consumption rates observed in Zimbabwe during April 1995 were $0.95 \mathrm{t} \mathrm{cap}^{-1} \mathrm{yr}^{-1}$ (wood), $0.13 \mathrm{t} \mathrm{cap}^{-1} \mathrm{yr}^{-1}$ (residues), and $0.004 \mathrm{t}$ $\mathrm{cap}^{-1} \mathrm{yr}^{-1}$ (dung). The urban population used fuelwood at a rate of $0.56 \mathrm{t} \mathrm{cap}^{-1}$ $\mathrm{yr}^{-1}$. Unlike in other African countries, the use of charcoal was not observed even in urban areas. The observed consumption rates are slightly lower than values previously reported for rural Zimbabwe (Grundy et al., 1993; Hemstock and Hall, 1995). Overall, the observed consumption rates support the proposal of Hall et al. (1994) that consumption rates of about $1,000 \mathrm{~kg} \mathrm{cap}^{-1} \mathrm{yr}^{-1}$ (rural) and $500 \mathrm{~kg}$ $\mathrm{cap}^{-1} \mathrm{yr}^{-1}$ (urban) provide a reasonable estimate for Africa.

Combining the per capita consumption rates, which were established during our biofuel survey, with the rural (7.64 Million) and urban (3.62 Million) population of Zimbabwe for the year 1995 (Marufu et al., 1997) results in an annual national consumption of $9.3 \mathrm{Tg}$ wood, $1.0 \mathrm{Tg}$ maize residues, and $0.1 \mathrm{Tg}$ dung. We assume an average moisture content of $15 \%$ mcdb, which falls between the value of $9 \%$ observed during the measurements in April 1995 and the generally suggested value of 20\% (Leach and Gowen, 1987; Hall et al., 1994). With this assumption, applying 
our emission factors presented in Table I yields a release of $4.1 \mathrm{Tg} \mathrm{CO}_{2}-\mathrm{C} \mathrm{yr}^{-1}$, $0.37 \mathrm{Tg} \mathrm{CO}-\mathrm{C} \mathrm{yr}^{-1}$, and $6.0 \mathrm{Gg} \mathrm{NO}-\mathrm{N} \mathrm{yr}^{-1}$ from domestic biomass burning in Zimbabwe. The importance of these emissions can be seen from comparison with emissions of $2.0 \mathrm{Tg} \mathrm{CO}_{2}-\mathrm{C} \mathrm{yr}^{-1}, 0.11 \mathrm{Tg} \mathrm{CO}-\mathrm{C} \mathrm{yr}{ }^{-1}, 8.9 \mathrm{Gg} \mathrm{NO}-\mathrm{N} \mathrm{yr}{ }^{-1}$ in Zimbabwe from vegetation burning in 1992, which have recently been assessed by Scholes et al. (1996). Although the emission estimates of Scholes et al. may be unusually low due to draught conditions in 1992, we conclude that for Zimbabwe, the release from domestic burning will be on the same order of magnitude or even higher than those from vegetation burning. The significance of domestic biomass burning for the regional trace gas budget remains prominent, even if other major sources are considered. This is particularly true for partially oxidized compounds like $\mathrm{CO}$. The annual release of $\mathrm{CO}$ from burning of fossil fuels in the industrial and transport sector in Zimbabwe amounts to 0.001 and $0.11 \mathrm{Tg} \mathrm{CO}-\mathrm{C} \mathrm{yr}^{-1}$, respectively (Maya et al., 1992). Thus, a major fraction of Zimbabwes CO production originates from domestic biomass burning, which creates a continuous background level of pollution. Because wood is low in $\mathrm{N}$, the contribution of domestic biomass burning to the $\mathrm{NO}_{x}$-budget will be relatively low, provided wood is the major fuel. Biogenic soil emissions, which have been estimated as $22.2 \mathrm{Gg} \mathrm{N} \mathrm{yr}^{-1}$ (Meixner et al., 1997) to $32.9 \mathrm{Gg} \mathrm{N} \mathrm{yr}^{-1}$ (Kirkman et al., 2001 are likely to dominate the $\mathrm{NO}_{x}$-budget.

Finally, we estimate the global contribution of domestic biomass burning to the global inventory of trace gas emissions. Accurate estimates of the amount of fuel burned each year are essential for this purpose but very difficult to obtain. Table II presents global inventories given by FAO (1995) for the year 1993 and by Hall et al. (1994). The inventory of Hall et al., originally provided for the reference year 1987, was updated with the population of 1995 (United Nations, 1995), assuming that the per capita consumption rates remained constant. The two inventories are different in that Hall et al. include all forms of biofuels, whereas FAO values are restricted to wood and charcoal consumption. Moreover, FAO figures are based on marketed fuel and therefore certainly underestimate fuelwood consumption. For further analysis, we therefore use the updated global consumption of Hall et al. (1994). Another major uncertainty arises from the partitioning between fuelwood, agricultural residues, dung, and charcoal. While wood is certainly the dominant biofuel on a global scale, the extent to which it is used may vary from region to region. Rice straw has been reported as contributing more than $50 \%$ of all biofuels burned domestically in several regions of rural China (Xiaohua and Zhenming, 1996), and similar fractions have been reported for the use of dung in parts of India (Reddy and Ravindranath, 1987; Joshi, 1991). For our emission estimate we assume contributions of $80 \%$ for wood, $15 \%$ for agricultural residues, $2.5 \%$ for dung, and $2.5 \%$ for charcoal.

The estimates of domestic fire emissions of $\mathrm{CO}_{2}, \mathrm{CO}$, and $\mathrm{NO}$ are summarized in Table II. In conclusion, we find that combustion of biomass fuels is a major source of trace gases. The global release through domestic biomass burning con- 
Table II. Inventory of global biofuel consumption and corresponding emissions. Biofuel consumption: Ia, fuelwood for the year 1993 as given by FAO production statistics (1995) and converted to dry mass units with FAO conversion factors and a moisture content of $20 \%$ mcdb; Ib, charcoal for the year 1993 as given by FAO production statistics (1995); II, all biofuel types for the population of 1995 (United Nations, 1995) calculated with per capita consumption rates given on a national basis by Hall et al. (1994) for the reference year 1987. Initial energy consumption figures were converted to dry mass units with the conversion factor and the moisture content ( $20 \%$ mcdb) as suggested by Hall et al. (1994). The resulting consumption rates (in $\mathrm{dm} \mathrm{cap}^{-1} \mathrm{yr}^{-1}$ ), including all forms of biomass, are 0.87 (Africa), 0.56 (Asia), 0.49 (Latin America), 0.19 (Oceania), 0.83 (N. America), 0.17 (Europe), and 0.34 (former USSR). Emissions were estimated with our emission factors given in Table I and biofuel consumption in column II under the assumption that $80 \%$, $15 \%, 2.5 \%$, and $2.5 \%$ of the total consumption is in form of wood, residues, dung, and charcoal, respectively. Data on emissions from all anthropogenic sources are taken from M. Prather et al., 1995; D. Schimel et al., 1996)

\begin{tabular}{|c|c|c|c|c|c|c|c|}
\hline \multirow[t]{3}{*}{ Region } & \multirow{3}{*}{$\begin{array}{l}\text { Population } \\
(1995) \\
\text { millions }\end{array}$} & \multicolumn{3}{|c|}{ Biofuel consumption } & \multicolumn{3}{|c|}{ Emission } \\
\hline & & Ia & $\mathrm{Ib}$ & II & $\mathrm{CO}_{2}$ & $\mathrm{CO}$ & $\mathrm{NO}$ \\
\hline & & \multicolumn{3}{|c|}{ 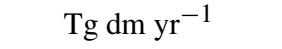 } & \multicolumn{3}{|c|}{$\operatorname{Tg} \mathrm{C}$ or $\mathrm{N} \mathrm{yr}^{-1}$} \\
\hline Africa & 728 & 265 & 11.5 & 633 & 296 & 28 & 0.50 \\
\hline Asia & 3386 & 517 & 3.8 & 1896 & 886 & 84 & 1.51 \\
\hline Latin America & 482 & 157 & 8.0 & 236 & 110 & 10 & 0.19 \\
\hline Oceania & 29 & 5 & 0.0 & 6 & 3 & 0 & 0.00 \\
\hline N. America & 293 & 59 & 0.5 & 243 & 114 & 11 & 0.19 \\
\hline Europe & 506 & 29 & 0.4 & 86 & 40 & 4 & 0.07 \\
\hline Former USSR & 292 & 30 & 0.1 & 99 & 46 & 4 & 0.08 \\
\hline World total & 5716 & 1062 & 24.3 & 3199 & 1495 & 141 & 2.54 \\
\hline \multicolumn{8}{|c|}{ All anthropogenic } \\
\hline sources & & & & & 7100 & 925 & 34 \\
\hline
\end{tabular}

stitutes about $17 \%\left(\mathrm{CO}_{2}\right), 13 \%(\mathrm{CO})$ and $6 \%(\mathrm{NO})$ of the overall budget (Andreae, 1993) of these compounds. About $85 \%$ of the domestic emissions are taking place in the developing countries of Asia, Africa, and Latin America.

Undoubtedly, the proposed emission estimates have a high degree of uncertainty. Although present knowledge does not allow an uncertainty analysis that is statistically defensible, the major error bounds can be made apparent. Emission ratios, especially $\Delta \mathrm{CO} / \Delta \mathrm{CO}_{2}$, show an encouraging uniformity. Based on the $90 \%$ confidence limits (as given in Figure 2) of the data set obtained in Zimbabwe at various locations and during different seasons, relative errors of less than $20 \%$ of the mean are calculated for each of the three fuel types used in the present study. The measurements in Nigeria and limited work by others (Brocard et al., 1996; Brocard and Lacaux, 1998; Smith et al., 1993) give consistent values and 
create some confidence that the average $\Delta \mathrm{CO} / \Delta \mathrm{CO}_{2}$ emission ratios derived in the present study will persist within given error limits on a global scale. A slightly higher uncertainty for the $\Delta \mathrm{NO} / \Delta \mathrm{CO}_{2}$ ratio may prevail owing to the varying nitrogen content of biofuels. These error ranges are minor, however, compared to the range of uncertainty in the annual amount of biomass burned as fuel. A difference of almost a factor of three for the annual biofuel consumption exists between the two global inventories summarized in Table II, and the uncertainty inherent in each inventory is difficult to judge. As discussed above, FAO statistics systematically underestimate the total biofuel consumption, and therefore, the figures for fuelwood and charcoal given in columns Ia + Ib of Table II provide a conservative lower limit for the total amount of biofuel consumption. On the other hand, per capita consumption rates reported in regional studies rarely exceed $1,300 \mathrm{~kg} \mathrm{cap}^{-1}$ $\mathrm{yr}^{-1}$ (20\% mcdb), and thus, this figure, when extrapolated to global dimensions, can serve to derive a robust upper limit. Using these values results in an uncertainty range of 1086 to $6192 \mathrm{Tg} \mathrm{dm} \mathrm{yr}^{-1}$ for the global biofuel consumption, equivalent to a range of 508 to $2894 \mathrm{Tg} \mathrm{C} \mathrm{yr}^{-1}$ for the corresponding $\mathrm{CO}_{2}$ release. Clearly, quantification of the annual global biofuel consumption is the major barrier to a more accurate estimate of emissions from domestic biomass burning, and improved knowledge of this consumption should be an urgent objective for future research. Attention also needs to be directed to the partitioning of the usage between the different types of biofuels. This can be illustrated by varying the contributions of the different fuels within reasonable limits, e.g., $60 \%$ wood, $25 \%$ agricultural residues, $7.5 \%$ dung, and $7.5 \%$ charcoal. With this partitioning, the amount of NO annually released from domestic biomass burning calculated is $3.55 \mathrm{Tg} \mathrm{N}$, which is about $40 \%$ higher than the value proposed in Table II.

Finally, it has to be noted that, in the case of $\mathrm{CO}_{2}$, the estimated release is not necessarily a net emission, as it depends on sustainability of woodfuel use. The use of residues and dung can be assumed to be $100 \%$ sustainable and will, therefore, contribute no $\mathrm{CO}_{2}$ net release to the atmosphere. For other compounds, however, the emissions given have to be seen as a net release. The importance of domestic biomass burning might still increase with population growth, which, however, will diminish available fuel for wild fires. As combustion efficiencies tend to be lower in domestic fires, the composition of the exhaust mixture will change, resulting in higher emissions of reduced compounds.

\section{Acknowledgements}

We would like to express our thanks to all persons in the households supporting our experiments for their hospitality. We are grateful to the Zimbabwean authorities for permission to carry out the work described. We are also indebted to the Department of Research and Specialist Services, Zimbabwe for providing the logistic support at the Soil Productivity Research Laboratory in Marondera. We acknowledge the help of C. Strametz in preparing this manuscript. This 
work was partially financed by BMBF-Project A2b-3 (Spurenstoffkreisläufe). L. T. Marufu is sponsored by a Max-Planck-Gesellschaft Graduate Fellowship. We also thank the reviewers for helpful comments. This research is a contribution to the International Global Atmospheric Chemistry (IGAC) Core project of the International Geosphere-Biosphere Programme (IGBP) and is part of the IGAC Biomass Burning Experiment (BIBEX).

\section{References}

Andreae, M. O., 1993: The influence of tropical biomass burning on climate and the atmospheric environment, in R. S. Oremland (ed.), Biogeochemistry of Global Change: Radiatively Active Trace Gases, Chapman and Hall, New York, pp. 113-150.

Barnard, G. W., 1990: Use of agricultural residues as fuel, in J. Pasztor and L. A. Kristoferson (eds), Bioenergy and the Environment, Westview Press, Boulder, pp. 85-112.

Brauer, M., Bartlett, K., Regalado-Pineda, J., and Perez-Padilla, R., 1996: Assessment of particulate concentrations from domestic biomass combustion in rural Mexico, Environ. Sci. Technol. 30, 104-109.

Brocard, D., Lacaux, C., Lacaux, J. P., Kouadio, G., and Yoboue, V., 1996: Emissions from the combustion of biofuels in western Africa, in J. S. Levine (ed.), Biomass Burning and Global Change, MIT Press, Cambridge, MA, pp. 350-360.

Brocard, D. and Lacaux, J. P., 1998: Domestic biomass combustion and associated atmospheric emissions in West Africa, Global Biogeochem. Cycles 12, 127-139.

Cahoon, D. R., Stocks, B. J., Levine, J. S., Cofer III, W. R., and O’Neill, K. P., 1992: Seasonal distribution of African savanna fires, Nature 359, 812-815.

Clements, H. B. and McMahon, C. K., 1980: Nitrogen oxides from burning forest fuels examined by thermogravimetry and evolved gas analysis, Thermochim. Acta 35, 133-139.

Christopher, S. A., Chou, J., Zhang, J., Li, X., Berendes, T. A., and Welch, R. M., 2000: Shortwave direct radiative forcing of biomass burning aerosols estimated using VIRS and CERES data, Geophys. Res. Lett. 27, 2197-2200.

Crutzen, P. J. and Andreae, M. O., 1990: Biomass burning in the tropics: Impacts on atmospheric chemistry and biogeochemical cycles, Science 250, 1669-1678.

Delmas, R., Lacaux, J. P., Menaut, J. C., Abbadie, L., LeRoux, X., Helas, G., and Lobert, J., 1995: Nitrogen compound emission from biomass burning in tropical African savanna FOS/DECAFE91, J. Atmos. Chem. 22, 175-193.

FAO, 1995: FAO Yearbook Forest Products 1982-1993, FAO Forestry Series No. 28, FAO, Rome, Italy.

Floor, W. and van der Plas, R., 1992: $\mathrm{CO}_{2}$ Emissions by the Residential Sector: Environmental Implications of Interfuel Substitution, World Bank Energy Series Pap. 51, World Bank, Nairobi, Kenya.

Grundy, I. M., Campbell, B. M., Balebereho, S., Cunliffe, R., Tafangenyasha, C., Fergusson, R., and Parry, D., 1993: Availability and use of trees in Mutanda Resettlement Area, Zimbabwe, Forest Ecol. Manage. 56, 243-266.

Hall, D. O. and Mao, Y. S., 1994: Biomass Energy and Coal in Africa, Zed Books, London.

Hall, D. O., Rosillo-Calle, F., and Woods, J., 1994: Biomass utilization in households and industry: Energy use and development, Chemosphere 29, 1099-1119.

Hemstock, S. L. and Hall, D. O., 1995: Biomass energy flows in Zimbabwe, Biomass Bioenergy 8, $151-173$

Joshi, V., 1991: Biomass burning in India, in J. S. Levine, (ed.), Global Biomass Burning, MIT Press, Cambridge, MA, pp. 185-193.

Kirkman, G. A., Yang, W. X., and Meixner, F. X., 2001: Global Biogeochem. Cycles 15, 1005-1020. 
de Koning, H. W., Smith, K. R., and Last, J. M., 1985: Biomass fuel combustion and health, Bull. WHO 63, 11-26.

Kituyi, E., Marufu, L., Wandiga, S. O., Jumba, I. O., Andreae, M. O., and Helas, G., 2001a: Biofuel availability and domestic use patterns in Kenya, Biomass Bioenergy 20, 71-82.

Kituyi, E., Marufu, L., Huber, B., Wandiga, S. O., Jumba, I. O., Andreae, M. O., and Helas, G., 2001b: Biofuel consumption rates and patterns in Kenya, Biomass Bioenergy 20, 83-99.

Leach, G. and Gowen, M., 1987: Household Energy Handbook, World Bank Technical Pap. 67, World Bank, Washington, D.C.

Levine, J. S., 1991: Global Biomass Burning, MIT Press, Cambridge, MA, p. 569.

Levine, J. S., 1996: Biomass Burning and Global Change, MIT Press, Cambridge, MA, pp. $902+$ 28.

Liousse, C., Dulac, F., Cachier, H., and Tanre, D., 1997: Remote sensing of carbonaceous aerosol production by African savanna biomass burning, J. Geophys. Res. 102, 5895-5911.

Lobert, J. M., 1989: Verbrennung pflanzlicher Biomasse als Quelle atmosphärischer Spurengase: Cyanoverbindungen, $\mathrm{CO}, \mathrm{CO}_{2}$ und $\mathrm{NO}_{x}$, Thesis, Johannes Gutenberg Universität, Mainz, Germany.

Marufu, L. T., Ludwig, J., Andreae, M. O., Meixner, F. X., and Helas, G., 1997: Domestic biomass burning in rural and urban Zimbabwe - Part A, Biomass Bioenergy 12, 53-68.

Marufu, L., Ludwig, J., Andreae, M. O., Lelieveld, J., and Helas, G., 1999: Spatial and temporal variation in domestic biofuel consumption rates and patterns in Zimbabwe: Implications for atmospheric trace gas emission, Biomass Bioenergy 16, 311-332.

Maya, R. S., Muguti, E., Fenhann, J., and Chigwada, J., 1992: UNEP greenhouse gas abatement costing studies - Zimbabwe country study - Phase 1, Southern Centre for Energy and Environment, Harare, Zimbabwe.

Meixner, F. X., Fickinger, T., Marufu, L., Serca, D., Nathaus, F. J., Makina, E., Mukurumbira, L., and Andreae, M. O., 1997: Preliminary results on nitric oxide emission from a southern African savanna ecosystem, Nutrient Cycling Agroecosyst. 48, 123-138.

Prather, M., Derwent, R., Ehhalt, D., Fraser, P., Sanhueza E., and Zhou, X., 1995: Other trace gases and atmospheric chemistry, in J. T. Houghton, L. G. Meira Filho, J. Bruce, H. Lee, B. A. Callander, E. Haites, N. Harris and K. Maskell (eds), Climate Change 1994, Cambridge University Press, Cambridge, U.K., pp. 73-126.

Reddy, A. K. N. and Ravindranath, N. H., 1987: Biomass, village energy and rural development, in D. O. Hall and R. P. Overend, (eds), Biomass: Regenerable Energy, Wiley, Chichester, U.K., pp. 387-411.

Schimel, D., Alves, D., Enting, I., Heimann, M., Joos, F., Raynaud, D., Wigley, T., Prather, M., Derwent, R., Ehhalt, D., Fraser, P., Sanhueaza, E., Zhou, X., Jonas, P., Charlson, R., Rodhe, H., Sadasivan, S., Shine, K. P., Fouquart, Y., Ramaswamy, V., Solomon, S., Srinivasan, J., Albritton, D., Isaksen, I., Lal, M., and Wuebbles, D., 1996: Radiative forcing of climate change, in J. T. Houghton, L. G. Meira Filho, B. A. Callander, N. Harris, A. Kattenberg, and K. Maskell (eds), Climate Change 1995 - The Science of Climate Change, Cambridge University Press, Cambridge, U.K., pp. 65-131.

Scholes, R. J., Ward, D. E., and Justice, C. O., 1996: Emission of trace gases and aerosol particles due to vegetation burning in the southern hemisphere Africa, J. Geophys. Res. 101, 23677-23682.

Smith, K. R., Aggarwal, A. L., and Dave, R. M., 1983: Air pollution and rural biomass fuels in developing countries: A pilot village study in India and implications for research and policy, Atmos. Environ. 17, 2343-2362.

Smith, K. R., Khalil, M. A. K., Rasmussen, R. A., Thorneloe, S. A., Manegdeg, F., and Apte, M., 1993: Greenhouse gases from biomass and fossil fuel stoves in developing countries: A Manila pilot study, Chemosphere 26, 479-505. 
Susott, R. A., Olbu, G. J., Baker, S. P., Ward, D. E., Kauffman, J. B., and Shea, R. W., 1996: Carbon, hydrogen, nitrogen, and thermogravimetric analysis of tropical ecosystem biomass, in J. S. Levine, (ed.), Biomass Burning and Global Change, MIT Press, Cambridge, MA, pp. 249-259.

United Nations, 1995: World Urbanization Prospects: The 1994 Revision, UN Department for Economic and Social Information and Policy Analysis, Population Division, New York.

Venkataraman, C. and Rao, G. U. M., 2001: Emission factors of carbon monoxide and size-resolved aerosols from biofuel combustion, Environ. Sci. Technol. 35, 2100-2107.

Woods, J. and Hall, D. O., 1994: Bioenergy for Development, FAO Environment and Energy Pap. 13, FAO, Rome.

Xiaohua, W. and Zhenming, F., 1996: Survey of rural household energy consumption in China, Energy 21, 703-705. 